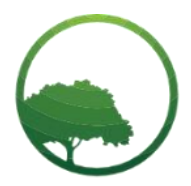

Research in Business \& Social Science

IJRBS VOL 10 NO 7 ISSN: 2147-4478

\title{
Career adaptability and career intention on government employees' years of service and job level
}

\author{
(D) Xy-Za Marie De Gulan ${ }^{(a)}$ (iD) Hector M. Aguiling ${ }^{(b)}$ \\ (a) The Graduate School, University of Santo Tomas, Philippines \\ (b) Professor, The Graduate School, University of Santo Tomas, Philippines
}

A R T I C L E I N F O
Article history:
Received 07 October 2021
Received in rev. form 25 Oct. 2021
Accepted 27 Sept 2021
Keywords:
Career intentions, career adaptability,
years in service, job level
JEL Classification:
M12, M51

\begin{abstract}
A B S T R A C T
Employees' level of career intention plays an important role in organizational readiness and dynamism to achieve success. Several studies were conducted on career adaptability and career intention, however, only a few were able to find evidence on the influence of position and years in service to government employees in the Philippines. This study aims to determine the significant differences in career adaptability and career intention of government employees based on years of service and job level. Results showed a significant difference in career intention when grouped according to job level and years in service and no significant difference in career adaptability when grouped according to job level and years in service.
\end{abstract}

(C) 2021 by the authors. Licensee SSBFNET, Istanbul, Turkey. This article is an open access article distributed under the terms and conditions of the Creative Commons Attribution (CC BY) license (http://creativecommons.org/licenses/by/4.0/).

\section{Introduction}

Employees' career behavior is driven by several factors. Trevor-Roberts et.al (2018) revealed that during challenging times, employees react differently based on employment relationships, organizational structure, employment arrangement, and communication. This was seconded by a study of Ito \& Brotheridge (2001) where they emphasized the influence of career control on the career flexibility and well-being of the employees. Human resource are susceptible to career shift and disruption due to lack of knowledge, opportunities, and resources to support basic needs.

Career intentions is defined as the individual's desire to aim higher career in the organization (Li \& Huang, 2017). It is driven by individual's personal values, psychological needs, perceived career success, and work environment (Kessler et al., 2019). Recent studies tackle a wider perspective on career intentions in terms of gender profile as they focus on work values, preferences, and perception about oneself. Career adaptability is defined as an ability and readiness of a person to adjust and respond to unpredictable changes in the work transitions and working conditions.

The career abilities have four subscales namely concern, control, curiosity and confidence, which were evaluated to improve and provide relevant insights to introduce various career models to address changes on work conditions, developmental tasks, and career transitions (Porfeli \& Savickas, 2012). Career adaptability was found to have significant relationship on intrinsic factors such as perfectionism (Wang et al, 2020), job insecurity (Urbanaviciute et al, 2020), emotional intelligence (Eryilmaz, 2020), career satisfaction (Coetzee \& Takawira, 2019); professional competence (Yang et al., 2015) and motivation (Kim \& Lee, 2015), among others. Meanwhile, career development, particularly the selection and promotion system, in the Philippine government agencies has been taunted with challenges on political and bureaucracy (Brillantes and Fernandez, 2011), which affects the employees' performance and career expectation. Hence, interventions that utilizes employees' profile and level of career adaptability must be explored to encourage employees to stay in the agency and increase their level of responsibility to lead to future promotion intention.

* Corresponding author. ORCID ID: 0000-0003-2412-1598

(C) 2021 by the authors. Hosting by SSBFNET. Peer review under responsibility of Center for Strategic Studies in Business and Finance.

https://doi.org/10.20525/ijrbs.v10i7.144 
This paper aims to determine the significant differences of employees' job position and years of service on the level of career adaptability and career intention. Several studies were conducted on the career adaptability and career intention, however, only few were able to find evidence on the influence of position and years in service to government employees in the Philippines. The result may determine whether having employees who serve the organization for long years and those who have senior positions provide competitive advantage to government institutions.

\section{Research and Development}

\section{Research Design}

The study utilized the qualitative research approach to determine the differences between career adaptability and career intention on years of service and job position of government employees.

\section{Participants}

The participants are from a government agency with regional offices and branches in the different Philippine regions occupying nonsupervisory positions. Using the purposive sampling technique, employees were selected based on employment status (permanent) and job position(non-supervisory) criteria. Of the 3,695 qualified employees, a total of 1,091 or 30\% of the target employees participated in the study. However, only 991 samples were considered after deleting the incomplete questionnaires.

Half of the target participants are holding senior positions at 533 or $53.78 \%$. Senior positions include legal officers, marketing officers, assistant managers, and senior executive assistants. While the rest of the participants hold entry positions such as administrative services, messenger, laborers, security guards, and specialists. Participants with less than 10 years of service constitutes to $50.55 \%$ or 501 . Those with $20-29$ and 30 above years of service share almost similar number at 74 (7.47\%) and 76 $(7.67 \%)$, respectively.

\section{Measure}

The instruments used are five-point Likert-type scales to measure the level of participant's agreement on the items relevant to determine their perceived level of career intention, and career adaptability. In addition to the instruments used, demographic characteristics such as years in service and job level were also collected.

Career Adapt-Abilities Scale - Short Form - is an abridge version of the widely used CASS International by Porfeli \& Savickas (2012) which measures the four adaptability resources: concern, control, curiosity, and confidence. The CAAS International was validated by Tolentino et al. (2013) to confirm the utility of CAAS in the Philippine context. The short form of the scale, which consists of 12 items, was developed by Maggiori, Rossier \& Savickas (2015) to allow easy integration of the survey to other battery of tests to reduce time spent on accomplishing the tool which is recommended in an organizational setting.

The short form was found to be strongly associated with full CAAS-International Form, with an overall Cronbach's coefficient alpha reliability (working samples) of 0.97 (Maggiori et.al, 2015). Likewise, the short form was validated and showed good overall Cronbach alpha coefficient for the entire scale ranging from 0.91 to 0.94 (Yu et.al, 2019).

Career Intention Questionnaire - was developed by De Gulan \& Aguiling (2021) to measure Philippine government employees' interest to accept new assignments and pursue higher positions in the organization. The tool has an overall Cronbach alpha coefficient of 0.82 .

\section{Procedure}

Since the study involves human subjects, the approval of an Ethics Committee was sought. This ensures that the methodology and handling of data follows the guidelines of conducting ethical research. Also, approval from the Head of the organization was requested prior to the conduct of the study. Consultation with concerned Departments was conducted to ensure that protocols on the proper handling of data were taken into consideration. Permission to use the instruments have also been requested from the author/data owner.

The questionnaires and the participant's Information and Informed Consent were deployed to target participants through email to follow the pandemic protocols. Access to answer the questionnaire was limited to 1 week. The email and consent form includes statement that participation is voluntary, expected duration of testing is 10-15 minutes, no discrimination and/or bias among rank and file, and non-participation will not result in any negative effects to their employment status.

\section{Statistical Analysis}

The research findings were presented in tables, graphs, and figures. Descriptive statistics such as frequency, mean, standard deviation, percentage, and analysis of variance (ANOVA) were analyzed using the SPSS software. 


\section{Findings}

Job Level. Table 1 shows the level of participants' career adaptability and career intention when grouped according to job level and years in service. Both employees holding entry and senior level positions scored above average on all constructs. Participants holding entry positions got higher scores on career adaptability $(\mathrm{M}=4.07, \mathrm{SD}=-.53)$ and career intentions $(\mathrm{M}=3.93, \mathrm{SD}=0.67)$ compared to participants holding senior positions. The ANOVA showed that there is a significant difference on the level of career intention $(\mathrm{F}=$ $10.67, \mathrm{p} \leq .01$ ) between participants' job level.

Table 1: Means, standard deviations, and analysis of variance of career adaptability and career intentions according to job level and years in service

\begin{tabular}{|c|c|c|c|c|c|c|c|}
\hline & \multirow[t]{2}{*}{$\mathbf{n}$} & \multicolumn{2}{|c|}{ Career Adaptability } & & \multicolumn{3}{|c|}{ Career Intentions } \\
\hline & & $\mathbf{M}$ & SD & $\mathbf{F}$ & $\mathbf{M}$ & SD & $\mathbf{F}$ \\
\hline Job Level & & & & 0.68 & & & $10.67 * *$ \\
\hline Entry level & 458 & 4.07 & 0.53 & & 3.93 & 0.67 & \\
\hline Senior level & 533 & 4.05 & 0.47 & & 3.78 & 0.75 & \\
\hline Years in Service & & & & 0.38 & & & $14.44 * *$ \\
\hline Less than 10 & 501 & 4.05 & 0.50 & & 3.95 & 0.63 & \\
\hline $10-19$ & 340 & 4.06 & 0.48 & & 3.80 & 0.79 & \\
\hline $20-29$ & 74 & 4.11 & 0.60 & & 3.84 & 0.77 & \\
\hline 30 above & 76 & 4.06 & 0.54 & & 3.40 & 0.72 & \\
\hline
\end{tabular}

Note: $\mathrm{M}=$ mean; $\mathrm{SD}=$ standard deviation; $\mathrm{F}=$ analysis of variance. $\mathrm{N}=991 .{ }^{*} \mathrm{p} \leq 0.05 ;{ }^{*} \mathrm{p} \leq 0.01$

The results suggest that employees with entry level positions (job levels 1-4) are more likely to signify their intention for higher positions and or signify interest to take on bigger roles and tasks. They are often characterized with positive perception of organizational support and career goal expectations when they entered the organization (Maxwell \& Broadbridge, 2010). Further, Takeuchi et.al (2021) also found that after a year they are hired, their positive organizational support shows positive changes in their career growth and organizational commitment.

On the other hand, employees with senior positions, are found to have mixed responses which may have influenced their level of career adaptability and career intentions. Because of their high level of job experience, they demonstrate high level of career adaptability, which they utilize to make constructive decisions and change-oriented work performance (Jiang et.al, 2018). However, their career intention may decrease due to limited future promotions (Imran et.al, 2020) as the next higher positions for employees with senior positions are managerial positions, which are considered to have a limited plantilla positions.

Years in service

On career adaptability, participants who are working in the organization for 20-29 years got higher scores on career adaptability $(\mathrm{M}=$ 4.11, $\mathrm{SD}=0.60)$ and those who are working less than 10 years scored lowest $(\mathrm{M}=4.05, \mathrm{SD}=0.50)$. While those with less than 10 years in service registered the highest on career intentions $(M=3.95, S D=0.63)$ and those who worked for 30 years above scored the lowest $(\mathrm{M}=3.40, \mathrm{SD}=0.72)$ on career intention. The ANOVA showed that there is a significant difference on the overall career intention $(\mathrm{F}=14.44, \mathrm{p} \leq .01)$ of participants.

The result provides evidence that the longer the employee's years of service they are less likely to signify to new tasks and aim for higher position in the organization. The decrease on the career intention may be the result of the changes in the organization. In an interview conducted by Van den Elsen \& Vermeeren (2019), employees share that the decrease on their level of career motivation is that the changes in their workload makes their work less enjoyable than before. Relevant to this, organization must determine programs that will engage employees and utilize the wealth of experience of employees with the most number of years in service. Researchers consider them as source of wisdom capital (Vasconcelos, 2018), workers who demonstrate professional vitality allowing organization benefits from their creativity, innovation, willingness to face challenges, agility, and productiveness (Van der Heijden et.al, 2009).

The higher score of employees working for 20-29 years in the organization on the level of adaptability is supported by the study conducted by Jiang et.al (2018) where they found out that longer tenure allows employees to develop competencies to perform their tasks as they take advantage of their job experience and accumulated knowledge over the years.

\section{Conclusions}

Study determined significant differences between employees' level of career adaptability and career intention when grouped according to years of service and job level. Interestingly, results showed that there is significant difference on the level of career intention of entry level and senior level employees and on the employees' years in service. Both profiles does not have significant difference on the level of career adaptability. These findings provide relevant insights on how these profiles may be utilized to craft relevant programs based on employees' needs to support their career development and direction. 
While the validity and reliability were established, several limitations have been noted. First, regarding the sampling, convenience sampling was employed to only one target government agency. This limits the generalizability of the findings. Hence, wider participation of various government agencies will provide additional evidence on the differences on the level of career adaptability and career intention. And another limitation is the factors tested in the study. The constructs may be correlated to other factors such as organizational climate and other demographic profile.

\section{References}

Brillantes, Jr., A. \& Fernandez, M. (2011). Restoring Trust and Building Integrity in Government: Issues and Concerns in the Philippines and Areas for Reform. 2nd Annual International Conference of the Asian Association for Public Administration: Enhancing Public Trust in Changing Asian Societies, University of Indonesia, 7-9 February 2011. International Public Management Review

Coetzee, M., \& Takawira, N. (2019). Career satisfaction of professional women: The interplay between career adaptability and psychosocial career preoccupations. African Journal of Employee Relations, 43(3764), 1-17. https://doi.org/10.25159/25203223/3764

De Gulan, X. \& Aguiling, H. (2021). Measure of Government Employees' Career Intentions: Design and Validation of Questionnaire. European Journal of Education Studies,8(10), 121-128, https://doi.org/10.46827/ejes.v8i10.3933

Eryilmaz, A., Satici B., \& Deniz M.E. (2020). A model of career adaptability for teachers: emotional intelligence, goal setting, and striving for goals. International Online Journal of Primary Education, 9(1), 63-72.

Imran, M., Elahi, N., Abid, G., Ashfaq, F. \& Ilyas, S. (2020). Impact of Perceived Organizational Support on Work Engagement: Mediating Mechanism of Thriving and Flourishing. Journal of Open Innovation: Technology, Market, and Complexity, 6, 82. https://doi.org/10.3390/joitmc6030082

Ito, J. \& Brotheridge, C. (2001). An Examination of the Roles of Career Uncertainty, Flexibility, and Control in Predicting Emotional Exhaustion, Journal of Vocational Behavior, 59(3), 406-424. https://doi.org/10.1006/jvbe.2001.1800

Jiang, Z. Hu, X. \& Wang, Z. (2018). Career Adaptability and Plateaus: The Moderating Effects of Tenure and Job Self-Efficacy. Journal of Vocational Behavior, 104. https://doi.org/10.1016/j.jvb.2017.10.006

Kessler, I., Bach, S., \& Nath, V. (2019). The construction of career aspirations amongst healthcare support workers: beyond the rational and the mundane?. Industrial Relations Journal, 50(2), 150-167. https://doi.org/10.1111/irj.12245

Kim, N.R., and Lee, K.H. (2015). The effect of internal locus of control on career adaptability: the mediating role of career decisionmaking self-efficacy and occupational engagement. American Counseling Association, 55, 2-15. https://doi.org/10.1002/joec.12069

Li, Y., and Huang, S. (2017). Hospitality service climate, employee service orientation, career aspiration and performance: A moderated mediation model. International Journal of Hospitality Management, 67, $24-32$. https://doi.org/10.1016/j.ijhm.2017.07.012

Maggiori, C., Rossier, J. \& Savickas, M. (2015). Career Adapt-Abilities Scale-Short Form (CAAS-SF): Construction and Validation. Journal of Career Assessment, 1-14. https://doi.org/10.1177/1069072714565856

Maxwell, G., Ogden S., \& Broadbridge, A. (2010). Generation Y's career expectations and aspirations: Engagement in the hospitality industry. Journal of Hospitality and Tourism Management, 17, 53-61. https://doi.org/10.1375/jhtm.17.1.53

Porfeli, E., \& Savickas M. (2012). Career Adapt-Abilities Scale-USA form: Psychometric properties and relation to vocational identity. Journal of Vocational Behavior, 80(3), 748-753. https://doi.org/10.1016/j.jvb.2012.01.009

Takeuchi, N., Takeuchi, T. \& Jung, Y. (2021). Making a successful transition to work: A fresh look at organizational support for young newcomers from an individual-driven career adjustment perspective. Journal of Vocational Behavior, $128,103587$. https://doi.org/10.1016/j.jvb.2021.103587.

Tolentino, L., Garcia, P.R.J., Restubog, S.L., Bordia, P., and Tang, R. (2013). Validation of the Career Adapt-Abilities Scale and an examination of a model of career adaptation in the Philippine context. Journal of Vocational Behavior, 83(3), 410-418. https://doi.org/10.1016/j.jvb.2013.06.013

Trevor-Roberts, E., Parker, P. \& Sandberg, J. (2018). How uncertainty affects career behaviour: A narrative approach. Australian Journal of Management, 44(1), 50-69. https://doi.org/10.1177/0312896218775801

Urbanaviciute, I., Udayar, S., Maggiori1, C., and Rossier, J. (2020). Precariousness profile and career adaptability as determinants of job insecurity: A three-wave study. Journal of Career Development, 47(2) 146-161. doi: 10.1177/0894845318791777

van den Elsen, J. and Vermeeren, B. (2020). Age and sustainable labour participation: studying moderating effects. International Journal of Manpower, 41(5), 503-521. https://doi.org/10.1108/IJM-10-2018-0362

van der Heijden, B., De Lange, A., Demerouti, E. \& Van der Heijde, C. (2009). Employability and career success across the lifespan. Age effects on the employability-career success relationship. Journal of Vocational Behavior, 74(2), 156-164. https://doi.org/10.1016/j.jvb.2008.12.009

Vasconcelos, A. (2018). Older workers as a source of wisdom capital: broadening perspectives. Revista de Gestão, 25(1), $102-118$. https://doi.org/10.1108/REGE-11-2017-002

Wang, D., Hou, Z.J., Ni, J., Tian, L., Zhang, X., Chi, H.Y., and Zhao, A. (2020). The effect of perfectionism on career adaptability and career decision-making difficulties. Journal of Career Development, 47(4), 469-483. https://doi.org/10.1177/0894845318803192/ 
Yang, W., Guan, Y., Lai, X., She, Z., \& Lockwood, A.J. (2015). Career adaptability and perceived overqualification: Testing a dualpath model among Chinese human resource management professionals. Journal of Vocational Behavior, 154-162. https://doi.org/10.1016/j.jvb.2015.08.007

Yu, H., Dai, Y., Guan, X. \& Wang, W. (2019). Career Adapt-Abilities Scale-Short Form (CAAS-SF): Validation Across Three Different Samples in the Chinese Context. Journal of Career Assessment, 20(10), 1-20. https://doi.org/10.1177/1069072719850575

Publisher's Note: SSBFNET stays neutral with regard to jurisdictional claims in published maps and institutional affiliations.

\section{(9) (1)}

(C) 2021 by the authors. Licensee SSBFNET, Istanbul, Turkey. This article is an open access article distributed under the terms and conditions of the Creative Commons Attribution (CC BY) license (http://creativecommons.org/licenses/by/4.0/).

International Journal of Research in Business and Social Science (2147-4478) by SSBFNET is licensed under a Creative Commons Attribution 4.0 International License. 